\title{
DIGITALNA TRANSFORMACIJA POSLOVANJA U MALOPRODAJI
}

\author{
Luka Burilović30
}

UDC / UDK: 004:658:339.37(497.5)

JEL classification / JEL klasifikacija: O3, L81

DOI: https://doi.org/10.22598/pi-be/2020.14.2.197

Scientific review / Pregledni znanstveni rad

Received / Primljeno: July 19, 2020 / 19. srpnja 2020.

Accepted for publishing / Prihvaćeno za tisak: September 28, 2020 / 28. rujna 2020 .

\section{Sažetak}

U radu se analizira proces digitalne transformacije s posebnim naglaskom na stanje digitalne transformacije u sektoru maloprodaje u Republici Hrvatskoj. Pored analize ključnih elementa same digitalne transformacije, analize globalnih promjena $u$ sektoru maloprodaje i njegove digitalizacije, za potrebe rada provedeno je istraživanje koje je potvrdilo pretpostavke o digitalnoj spremnosti maloprodaje u RH, kao i o stanju digitalizacije iste te stanju digitalne transformacije. Naime, iako je velika većina poduzeća iz uzorka svjesna izazova koje nosi novo digitalno okruženje, digitalizacija $i$ digitalna transformacija nisu svim akterima u sektoru prioritet. Razlozi za nečinjenje su vrlo često financijske ili operativne prirode. Najveća pozornost poduzeća iz sektora je usmjerena na razvoj novih digitalnih platformi, a interno se primarno fokusiraju na digitalizaciju internih procesa. Fokus na potrošače i cjelokupne odnose s njima još uvijek je sekundarna tema u procesu digitalizacije i digitalne transformacije poduzeća iz sektora maloprodaje. Također, poduzeća iz sektora maloprodaje u ovom istraživanju jasno se mogu podijeliti $u$ skupinu onih koja aktivno rade na digitalizaciji $i$ digitalnoj transformaciji i ona koja to ne čine.

Ključne riječi: digitalna transformacija poslovanja, digitalizacija, novi poslovni modeli, maloprodaja, Hrvatska.

\section{UVOD}

Sektor maloprodaje nalazi se središtu digitalne disrupcije koja se događa $u$ svijetu, Europi i Hrvatskoj. Nalazimo se u vremenu kada tradicionalni tržišni igrači, suočeni s novim navikama potrošača stečenim tijekom krize izazvane pandemijom

30 Dr. sc. Luka Burilović, predsjednik Hrvatske gospodarske komore, E-mail: lburilovic@hgk.hr 
korona-virusa, pokušavaju ući u tržišne segmente i niše koristeći mogućnosti koje nudi digitalni svijet. Navedeno je i jedan od ključnih motiva za sve učestalije rasprave o potencijalima digitalne transformacije $\mathrm{i}$ potrebi redefiniranja poslovnih strategija $\mathrm{i}$ planova s ključnim naglaskom na individualne zahtjeve potrošača. Stoga je i osnovni cilj ovoga rada istražiti i analizirati trenutno stanje digitalizacije i digitalne transformacije $u$ sektoru maloprodaje u RH te ispitati razumijevanje, stajališta i stavove poduzeća u ovome sektoru o samoj tematici digitalne transformacije.

Prvi dio rada bavi se općenito temom i shvaćanjem digitalne transformacije. U drugom dijelu dan je kratki prikaz stanja digitalne transformacije u Republici Hrvatskoj, dok su u trećem dijelu navedeni i analizirani ključni elementi uspješne digitalne transformacije. Četvrti dio rada bavi se promjenama u sektoru maloprodaje i njegovom digitalizacijom, dok su u petom dijelu prikazani rezultati istraživanja o digitalnoj transformaciji u sektoru maloprodaje u RH. U zadnjem dijelu rada, izvedeni su zaključci i dane preporuke za digitalnu transformaciju poslovanja poduzeća u sektoru maloprodaje u RH.

\section{OPĆENITO O DIGITALNOJ TRANSFORMACIJI POSLOVANJA}

Digitalna transformacija poslovanja danas je jedan od najviše korištenih pojmova u poslovnim publikacijama, portalima i razgovorima između poslovnih ljudi (Von Leipzig et al. 2017; Kaufman i Horton 2014). Vjerojatno ne postoji uspješan menadžer ili perspektivan poduzetnik koji se nije zapitao što digitalna transformacija znači za poslovanje njegove organizacije. S druge strane, iako je, već više od dva desetljeća, vidljiv utjecaj digitalnih tehnologija ne samo na poduzeća i njihovo poslovanje, već i šire, na čitav spektar društvenih aktivnosti, sam koncept digitalne transformacije nedovoljno je istražen u znanstvenoj literaturi, što rezultira „nejasnim i mutnim razumijevanjem cjeline digitalne transformacije“ (Tekic i Koroteev 2019). Samim time, niti pojam digitalne transformacije nije jednoznačno definiran (Schallmo et al., 2017).

Od mnogobrojnih definicija digitalne transformacije u recentnoj literaturi, za potrebe ovog rada preuzeta je sljedeća: „Digitalna transformacija definira se kao promjena $u$ načinu na koji poduzeće koristi digitalne tehnologije za razvoj novog digitalnog poslovnog modela koji pomaže stvoriti i priskrbiti veću vrijednost za poduzeće“" (Verhoef et al., 2019). S obzirom da se u radu specifično analiziraju poduzeća iz sektora maloprodaje te njihova spremnost da se digitalno transformiraju ne bi li zadržala/povećala vlastite tržišne pozicije i poboljšala svoje poslovne performanse, smatra se da je ova, relativno široka definicija koncepta digitalne transformacije vrlo prikladna za tu svrhu.

Ubrzavanje procesa digitalne transformacije poslovanja se danas događa $u$ tolikom obujmu da je suvremeni poduzetnici i menadžeri istovremeno smatraju i prijetnjom i prilikom. U izvješću pod naslovom „Godišnje izvješće o internetu“ CISCO Systems procijenio je da će u 2023. gotovo dvije trećine globalne populacije imati pristup internetu. Nadalje, u istom izvješću stoji da će u 2023. više od 29 milijardi uređaja biti 
spojeno na Internet, što je porast od više od 10 milijardi novih uređaja spojenih na Internet u odnosu na 2018. godinu.

Početke proučavanja tematike digitalne transformacije poslovanja nalazimo $\mathrm{u}$ knjizi utemeljitelja MIT Media Laba, Nicholasa Negropontea, iz 1995. godine koja se bavi istraživanjem zamjenjivosti bita i atoma (Marchand i Wade 2014). U knjizi se navodi kako se bilo koji oblik informacije koja postoji kao atom (poput knjiga i DVD-a), može predstaviti bitovima na digitalnom uređaju. Ova pretpostavka/tvrdnja temelj je ranom rastu e-trgovine, kao i raširenoj primjeni u tradicionalnijim industrijskim informacijskim sustavima, na primjer, praćenju pošiljaka FedEx-om, upravljanju zalihama od Walmarta, te svakodnevnom praćenju kupovine milijuna Frito-Lay grickalica od strane vozača prodajnih ruta. Čelnici ovih poduzeća shvatili su da su digitalne informacije o njihovim proizvodima (i kupcima) jednako važne za jačanje poslovnog učinka kao i sami proizvodi. Otada su napredne i najuspješnije organizacije uveliko transformirale poslovanje primjenom digitalnih tehnologija, digitalizirale poslovne procese i općenito postale digitalno pametnije, ali često na $a d-h o c$ način, bez prevladavajuće strukture ili odgovarajuće digitalne strategije. Međutim, digitalnu transformaciju poslovanja treba shvatiti kao putovanje organizacije kojem se mora pristupiti pažljivo, mudro i strukturirano.

Mnoge organizacije, poduzetnici i menadžeri nisu dovoljno upoznati s pojmom digitalne transformacije poslovanja te je poistovjećuju s digitalizacijom postojećih poslovnih modela $\mathrm{i} / \mathrm{ili}$ analognih procesa i rješenjima informacijsko-komunikacijske tehnologije, poput $C R M$-a, ERP-a i drugih alata koji služe kao potpora u suvremenom poslovanju. Međutim, kao što su istaknuli Wessel i ostali (2020), gore navedeno poimanje, digitalne transformacije, ili bolje rečeno nerazumijevanje, se svodi na „organizacijsku transformaciju potpomognutu digitalnim tehnologijama “ (Wessel et al, 2020), dok je sama digitalna transformacija koncept rezerviran za mnogo dublje strukturne promjene u poduzeću.

Nadalje, ono što proces digitalne transformacije poduzeća razlikuje od gore navedenog procesa je razvoj inovativnog poslovnog modela, kreiranje i efikasno korištenje inovacijskog sustava organizacije pri stvaranju novih usluga/proizvoda te potpuna reorganizacija sustava (Wessel et al., 2020) To je, i sadržajno, puno zahtjevniji proces za koji je nužna aktivna uloga upravljačke strukture poduzeća radi provedbe transformacije na svim razinama. Može se zapravo reći da digitalna transformacija predstavlja transformaciju poslovanja organizacije (i posljedično reorganizaciju koja je usklađena s transformiranim poslovanjem) korištenjem digitalnih alata.

\section{DIGITALNA TRANSFORMACIJA POSLOVANJA U HRVATSKOJ - HRVATSKI DIGITALNI INDEKS (HDI)}

O stanju digitalne transformacije u Hrvatskoj ne postoji dovoljno odgovarajućih podataka koji bi osigurali objektivnu sliku stanja, kako na razini poduzeća ili korporacije, tako i na razini hrvatskog gospodarstva. Rezultati studije digitalne transformacije provedene u Hrvatskoj u razdoblju od listopada 2018. do rujna 2020. godine ukazuju na 
nedovoljnu pripremljenost hrvatskog gospodarstva za izazove digitalnog doba (Ćurić Martinčević 2020). Prema rezultatima studije, gotovo svako drugo poduzeće u Hrvatskoj smatra da se digitalna transformacija nalazi među deset najvažnijih tema, no velika većina njih vjeruje kako će digitalne izazove jednostavno riješiti digitalizacijom analognih poslovnih procesa. Upravo zato većina poduzeća prepušta upravljanje izazovima digitalne transformacije IT odjelu poduzeća. Međutim, oni bolje upućeni razumiju da se digitalna transformacija ne odnosi samo na promjene IT sustava, već da ona obuhvaća sve segmente poslovanja organizacije (ljude, kulturu, procese, partnere i drugo). Upućeniji članovi poslovne zajednice poimaju digitalnu transformaciju kao digitalnu transformaciju poslovanja - temeljitu promjenu u organizaciji i načinu tradicionalnog poslovanja, korištenjem digitalnih tehnologija i primjenom novih poslovnih modela $\mathrm{s}$ ciljem poboljšanja performansi organizacije i brže prilagodbe u okruženju koje se stalno i brzo mijenja. Studija Hrvatskog digitalnog indeksa (Ćurić Martinčević 2020) daje pregled stanja digitalne transformacije u Hrvatskoj iz takozvane bottom-up perspektive. To znači da su ukupni rezultati studije zbroj individualnih izvještaja o stanju digitalne transformacije tristo najboljih srednjih i velikih poduzeća.

Hrvatski Digitalni Indeks iz 2020. godine nam daje jasan uvid u stanje digitalizacije u RH. Naime, svega $17,7 \%$ poduzeća u RH ima razvijenu strategiju digitalne transformacije dok istovremeno, čak $25,1 \% \%$ ispitanika nema namjeru razviti strategiju digitalne transformacije. Nadalje, $88 \%$ ispitanika smatra da će digitalna transformacija, bilo uspješna ili neuspješna, ostaviti posljedice na poslovanje poduzeća.. S obzirom na rezultata ankete, može se zaključiti da rukovodstva poduzeća ne prepoznaju dovoljno nužnost prilagodbe poslovanja promjenama u okruženju niti prilike koje digitalno doba pruža za unaprjeđenje konkurentnosti.

\section{KLJUČNI ELEMENTI USPJEŠNIH DIGITALNIH TRANSFORMACIJA POSLOVANJA}

Za uspješnu digitalnu transformaciju poslovanja nužna je promjena načina razmišljanja (mentalnog sklopa) i korporativne kulture organizacije, što je i prepoznato kao jedan od ključnih dimenzija procesa digitalne transformacije (Gurbaxani i Dunkle 2019; Warner i Wager 2019)). Iako kod nekih menadžera postoji mišljenje da transformacija uvijek dovodi do kanibalizacije postojećih proizvoda i usluga, to nikako ne mora biti tako. Digitalna transformacija nudi poduzeću i zaposlenicima dugoročnu perspektivu održivog poslovanja i nužna je za postizanje i održavanje konkurentnosti tvrtke. Dobro organizirana i implementirana transformacija poslovanja se ne prelama na leđima zaposlenika, već im osigurava mogućnosti boljeg fokusa na prioritete $u$ poslovanju, spremnost da odgovore na promjene u okruženju (agilnost), te bolju mogućnosti dugoročnog razvoja karijere, znanja i vještina (Meske i Junglas, 2020)

Digitalna transformacija nije jednokratan, kozmetički pothvat, već je temeljita promjena $\mathrm{u}$ organizaciji i načinu tradicionalnog poslovanja, korištenjem digitalnih tehnologija i novih poslovnih modela, a sve s ciljem poboljšanja performansi organizacije i brže prilagodbe okruženju. Stoga je, kao i kod svih strateških promjena, nužna osobna 
uključenost i odgovornost najutjecajnijih dionika organizacije, te predanost digitalnoj transformaciji od strane top menadžmenta.

Iskustva konzultanata stečena prilikom savjetovanja prilagodbe poslovanja digitalnom dobu ukazuju da je važno da poduzeća definiraju i ažuriraju svoju strategiju, a potom i poslovni plan koji u sebi treba sadržavati komponente digitalne transformacije. Nužno je da plan bude precizan i konkretan, da sadrži jasne smjernice i jasna zaduženja za svaki od dijelova poslovnog sustava poduzeća. Drugim riječima, digitalna strategija mora biti ugrađena/integrirana u sve strateške dokumente poduzeća i poslovne planove, a nikako ne bi trebala biti samo još jedan zasebni dokument koji će samo neki rukovoditelji smatrati ključnim za razvoj poslovanja. Naime, u literaturi je prepoznato da su strategija i njezina implementacija ključni faktori za uspješnu provedbu procesa digitalne transformacije (Kane et al., 2015).

Za uspješnu digitalnu transformaciju nužno je, također, da ona ima svog nositelja i da je to njegov primarni posao (Matt et al. 2015). Iz tog razloga sve više poduzeća u upravljačku strukturu ,dodaju“ funkciju direktora digitalne transformacije ili člana uprave za digitalnu transformaciju, koji bi trebao biti na najvišoj razini rukovodstva i koji snosi odgovornost za implementaciju digitalne transformacije (Haffke et al. 2016).

Kod strateškog planiranja digitalne transformacije poduzeća važno je znati da ona u većini slučajeva ne donosi brze i kratkoročne rezultate, te da je, u transformaciji, potrebno prepoznati dugoročne interese za poduzeće. Zbog kratkoročnih očekivanja dioničara ili kratkih mandata uprave, česta su očekivanja brzog povrata investicije. U implementaciji digitalne transformacije poslovanja ključne su dvije stvari. Prvo, odmah $\mathrm{u}$ početku pokušati što preciznije predvidjeti troškove. Naravno, nemoguće je potpuno predvidjeti troškove povezane s promjenom poslovne kulture ili organizacijskog ustroja, no dobrim planiranjem trebao bi se izbjeći nepotreban otpor kasnije u projektu. Drugo, nužno je postaviti mjerljive pokazatelje uspješnosti na samom početku provedbe. Jedino je tako nakon provedbe moguće valorizirati rezultate digitalne transformacije. Važno je imati na umu i kako ulaganje u digitalnu transformaciju nije trošak, već investicija $s$ konkretnim povratom u budućnosti.

\section{PROMJENE U SEKTORU MALOPRODAJE I NJEGOVA DIGITALIZACIJA}

Maloprodaja je danas suočena s velikim izazovima zbog velike mobilnosti potrošača, potrebe za snažnom orijentacijom na praćenje i analizu ponašanja potrošača, te prelaska na online, odnosno e-trgovinu. Stoga je digitalna transformacija poslovanja maloprodaje neizbježna te je potrebno mudro provesti sve prilagodbe što je prije moguće. Organizacijama, pri tome, mogu pomoći i disruptivna, i na tržištu dokazana, rješenja koja pomažu ubrzanju njihove transformacije. Sam pojam disrupcije, baš poput pojma digitalne transformacije, nije u znanstvenoj literaturi jednoznačno definiran te, kako ističu Klikki et al. (2018), većina definicija iz literature proizlazi iz ,potrage za zajedničkim nazivnikom“ "iz skupa disruptivnih procesa koji se u tu svrhu proučavaju. Za potrebe ovog rada, disrupcija se definira kao ,brzi proces kroz koji digitalne inovacije u osnovi 
mijenjaju povijesno održivu logiku stvaranja i prisvajanja vrijednosti, razdvajanjem i ponovnim kombiniranjem veza među resursima ili stvaranjem novih" (Skog et al. 2018). Mnoga poduzeća u sektoru maloprodaje danas iskušavaju inovativne metode transformacije poslovanja kao odgovor na dva čimbenika koji će tek postati ključni u narednim godinama. Prvo, broj novopridošlih potrošača na tržištu pojačava konkurenciju na lokalnoj, regionalnoj i globalnoj razini. Poduzeća se moraju natjecati sa skupinama koje imaju niz komparativnih prednosti, a jedna od ključnih je efikasnija proizvodnja i optimalno organizirana distribuciji proizvoda i usluga. U današnjem svijetu potrošači imaju mogućnost izbora više nego ikada prije pa je stoga ključno privući njihovu pažnju i interes za robne marke koje se žele prodati. Drugo, eksponencijalni rast i sve snažnija primjena novih tehnologija u maloprodaji značajno je promijenila način na koji se proizvodi ili usluge proizvode, prodaju i konzumiraju. Da bi se zadržale vodeće pozicije pred sve jačom konkurencijom i disruptorima koji dolaze sa svih strana, postojeći tržišni lideri moraju uvijek nastojati biti korak ispred ili barem držati korak s inovativnim poslovnim modelima i novim praksama poslovanja u digitalnom dobu (Kilkki et al., 2018).

\subsection{Digitalizacija maloprodaje}

Digitalni svijet doveo je do radikalnih promjena u tradicionalnoj maloprodajnoj praksi, ali to nije naštetilo ili zaustavilo prodaju, nego upravo suprotno. Digitalna tehnologija podržava i pojednostavljuje fizičku kupnju potrošača dok poduzećima omogućuje prikupljanje dodatnih i važnih informacija o potrošačima. Digitalizacijom poslovanja i procesa poduzeća postaju fleksibilnija i mogu puno lakše uskladiti marketinšku strategiju s promjenama u okruženju i potrebama potrošača. Inovativna i kolaborativna suradnja poduzeća i potrošača je izazov, ali istovremeno i velika prilika za rješavanje pitanja vezanih uz neprestane promjene u preferencijama potrošača.

Digitalizacija poslovanja otvara mogućnosti potpunog redizajna načina prikupljanja podataka u trgovinama - fizičkim prostorima (Pantano i Vanucci 2019). Trgovina budućnosti mora biti mjesto koje u potpunosti integrira sve aspekte potrošačeva digitalnog putovanja, od razmišljanja o proizvodu ili usluzi, preko pretraživanja i emocija u trgovini, pa do same kupnje i stvaranja lojalnosti, i sve to nenametljivo i skoro neprimjetno, a što je i omogućeno automatizacijom i digitalnim tehnologijama. Ovakav pristup zahtijeva prilagodbu načina rada samih trgovaca, koji se trebaju upoznati s inovativnim poslovnim alatima, analizirati uobičajene rutine poslovanje, eksperimentirati s novim poslovnim modelima, te se precizno usredotočiti na poboljšanje zadovoljstva potrošača kroz učinkovito korištenje digitalnih tehnologija.

\subsection{Promjena poslovnog modela u sektoru maloprodaje}

S pojavom digitalnih disruptora kao agenata disruptivnih inovacija (Kilkki et al. 2018) u sektoru maloprodaje, granicu između digitalnog i fizičkog svijeta teško je povući. Gotovo svako poduzeće prepoznaje nužnosti digitalne transformacije, bilo kroz vlastite inicijative ili zbog pritiska konkurencije. Iako su se poslovni modeli s vremenom mijenjali, spajanje tehnologija poput pametnih telefona, rada u oblaku, društvenih mreža ili umjetne inteligencije, ubrzalo je dinamiku kojom se današnja poduzeća razvijaju te 
povećalo stupanj preobrazbe njihova poslovanja i načina na koji inoviraju, djeluju i opslužuju potrošača. Za neka tradicionalnija poduzeća digitalna je transformacija sila koja je poremetila njihovo poslovanje te na nju ne gledaju blagonaklono. Međutim, za druga poduzeća koja su otvorena za stalnu promjenu načina poslovanja i kontinuirano propitivanje poslovnog modela koji provode, digitalna transformacija poslovanja otvara vrata do sada neviđenim mogućnostima napretka, razvoja i rasta poslovanja. Kako trgovac može iskoristiti digitalnu disrupciju za promjenu poslovnog modela ovisi o fazi rasta poduzeća u kojem se ono nalazi, razini razumijevanja i podrške od strane najvišeg menadžmenta, te predanosti dugoročnom cilju digitalne transformacije koji uključuje $i$ toleranciju na pogreške koje će se zasigurno dogoditi na tom putu. Digitalna disrupcija kod inovativnih startup tvrtki otvara vrata inovativnim poslovnim modelima, sinergijskim proizvodima i uslugama, te im pomaže u povećanju lojalnosti postojećih i privlačenju novih kupaca (Skog et al. 2018). Postojećim poduzećima i liderima na tržištu maloprodaje digitalna disrupcija može pomoći u pronalasku boljih rješenja za smanjivanje prijetnji na tržištu i stvaranju novih eko-sustava. Analiza eksternog okruženja sektora maloprodaje ukazuje na snažan rast partnerstva te puno efikasnijeg korištenja podataka i inovacija na svim poljima. Kako god definirali razloge ovih disrupcija, s velikom sigurnošću se može zaključiti da su promjene navika potrošača ključan čimbenik promjena koje se moraju uzeti u razmatanje pri definiranju novih poslovnih modela zasnovanih na digitalnim tehnologijama, odnosno kao ideja vodilja $u$ procesu digitalne transformacije (Boureanu 2017).

Sve je više trgovaca koji koriste digitalne zajednice (mreže) i digitalne platforme za pružanje usluga, razmjenu iskustva i obavljanje osnovne djelatnosti (Hanninen et al 2018). Te aktivnosti rezultiraju stvaranjem novih kanala za interakciju s potrošačima $i$ novih načina za bolje korištenje resursa. Kako bi iskoristili ove mogućnosti, trgovci moraju pronaći nove načine prikupljanja podataka i to ne samo korištenjem senzora $\mathrm{i}$ analitike društvenih medija, već i načine koji su kompatibilni s rastućim digitalnim svijetom i njegovim potrošačima (Wessel i Christensen 2012).

\section{OBILJEŽJA PROVEDENOGA ISTRAŽIVANJA, OPIS UZORKA I REZULTATI ISTRAŽIVANJA O DIGITALNOJ TRANSFORMACIJI U SEKTORU MALOPRODAJE U RH}

Kako bi se provjerilo razumijevanje digitalne transformacije u sektoru maloprodaje u RH, utvrdila ,digitalna spremnost“" sektora maloprodaje $\mathrm{u}$ RH, te ispitalo stanje digitalne transformacije i njeni ključni čimbenici, tijekom svibnja i lipnja 2020. godine provedeno je empirijsko istraživanje na uzorku od 53 poduzeća u sektoru maloprodaje u RH. Za potrebe provedbe spomenutog empirijskoga istraživanja, kreiran je anketni upitnik i poslan na 150 adresa. Na upitnik je odgovorilo 53 poduzeća, a podatci o njihovoj strukturi prikazani su u nastavku.

Upitnik je sastavljen od 25 pitanja zatvorenog tipa s tim da je na 9 pitanja moguće ponuditi i više od jednog odgovora. Pitanja iz upitnika analizirana su koristeći deskriptivnu statistiku, gdje se pomoću proporcija odgovora na pitanja nastojalo zadobiti 
uvid u stanje digitalizacije i pripremljenost za digitalnu transformaciju poduzeća iz sektora maloprodaje u RH.

\subsection{Opis uzorka istraživanja}

Poduzeća su analizirana s obzirom na veličinu, pri čemu je kao mjera veličine poduzeća korišten broj zaposlenih. Približno jedna trećina poduzeća ima od 51 do 250 zaposlenih i pripada u skupinu srednje velikih poduzeća. Najmanje poduzeća u uzorku ima do 50 zaposlenih.

Distribucija poduzeća s obzirom na tradiciju (mjerenu godinama starosti) pokazuje nam da su u nešto većem broju zastupljena ona poduzeća koja posluju na tržištu 16 i više godina, a ima ih približno tri petine. Poduzeća koja posluju manje od 16 godina, u uzorku čine približno dvije petine.

Životni ciklus poduzeća iz uzorka stupnjevan je na temelju stopa rasta. Mlada poduzeća karakteriziraju visoke stope rasta. Rastuća poduzeća imaju veće stope rasta od rasta društvenog proizvoda. Zrela poduzeća imaju stope rasta jednake stopi rasta društvenog proizvoda ili stagnaciju, a stara poduzeća imaju višegodišnji pad prodaje.

Distribucija poduzeća iz uzorka s obzirom na životni ciklus je sljedeća: Najmanje je poduzeća iz mlade djelatnosti $(6 \%)$, zatim slijede poduzeća iz starih djelatnosti $(2004.10 \%$, 2005. 12\%), te djelatnosti u rastu (2004. 38\%, 2005. 34\%), a najviše je poduzeća iz zrelih djelatnosti (2004. 40\%, 2005. 45\%).

Rezultati istraživanja prikazani su kao tri zasebne cjeline koje, generalno gledajući, daju odgovore na sljedeća pitanja:

1. Kako poduzeća u sektoru maloprodaje u RH shvaćaju digitalnu transformaciju?

2. Kakav je stupanj digitalne spremnosti sektora maloprodaje u RH?

3. Kakvo je stanje digitalne transformacije poduzeća iz sektora maloprodaje u RH te koji su interni procesi poduzeća u sektoru maloprodaje u RH vezani za digitalizaciju poduzeća

\subsection{Rezultati empirijskog istraživanja digitalne transformacije sektora maloprodaje u Republici Hrvatskoj}

Pri definiranju pojma digitalne transformacije (Slika 1), najučestaliji izbor ispitanika, odnosi se na modifikaciju ili potpunu promjenu poslovnog modela poduzeća (oba odgovora izabralo je oko dvije trećine ispitanika). Nadalje, s jedne strane naglasak se stavlja na IT infrastrukturu, dok s druge strane, podjednak broj ispitanika smatra da je daljnji razvoj digitalnih kompetencija zaposlenika osnovna odrednica procesa digitalne transformacije. 
Slika 1. Digitalna transformacija

Što je po Vama digitalna transformacija? (Moguće je ponuditi više od jednog odgovora)

Ne znam/Nisam siguran

Jačanje digitalnih kapaciteta zaposlenika kroz treninge I edukacije

Integracija i optimizacija IT sustava

Razvoj novih digitalnih poslovnih modela

Digitalizacija postojećeg poslovnog modela i/ili analognih procesa

Izvor: izračun autora

Ocjena pripremljenosti za digitalizaciju, te stanje same digitalizacije sektora maloprodaje u RH (Slika 2) pokazuje da je više od polovice ispitanika svjesno da je stanje, ali i pripremljenost za buduću digitalizaciju sektora osrednja (preko 50\%) do slaba (preko $20 \%$ ). S obzirom da je sektor maloprodaje najizloženiji digitalnoj disrupciji, ovakva ocjena od strane poduzeća iz sektora predstavlja s jedne strane prijetnju etabliranim poduzećima u sektoru, ali s druge strane i potencijalnu priliku za nove igrače na tržištu maloprodaje. 
Slika 2. Stanje digitalizacije sektora maloprodaje u RH

Kako biste ocijenili stanje DIGITALIZACIJE hrvatskog sektora maloprodaje?

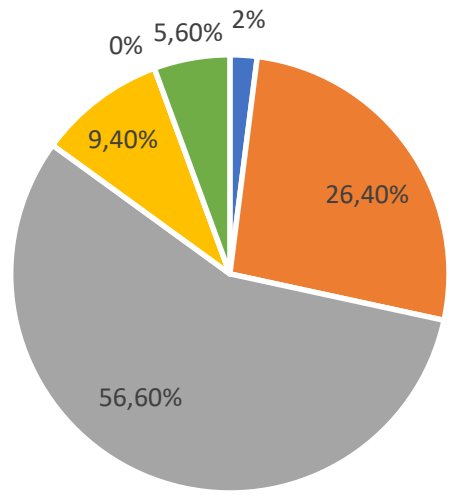

- Jako loše

- Slabo

- Dobro (osrednje)

- Vrlo dobro

- Odlično

- Ne znam/Nisam siguran/a

Izvor: izračun autora

Ocjena stanja digitalizacije podudara se s ocjenom pripremljenosti sektora maloprodaje za digitalizacije što je i bilo za očekivati (Slika 3). Diskrepancija u razumijevanju digitalne transformacije (Slika 1) potvrđena je i odgovorima o važnosti digitalne transformacije kao teme unutar poduzeća. 
Slika 3. Pripremljenost sektora maloprodaje za digitalizaciju

\section{Kakvo je Vaše mišljenje o pripremljenosti sektora maloprodaje u RH za DIGITALIZACIJU?}

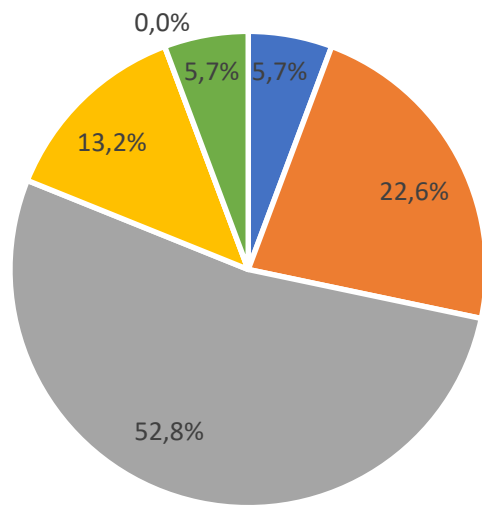

- Jako loše

- Slabo

- Dobro (osrednje)

- Vrlo dobro

- Odlično

- Ne znam/Nisam siguran/a

Izvor: izračun autora

Gotovo 50\% ispitanika je odgovorilo da je digitalna transformacija ili najvažnija ili među 3 najvažnije teme u poduzeću (Slika 4). Ono što zabrinjava je da je više od 15 posto ispitanika odgovorilo da digitalna transformacija uopće nije na listi prioriteta $\mathrm{u}$ njihovim poduzećima. Ukoliko tom broju pridodamo i ona poduzeća kojima je to tek među prvih deset prioriteta (34\%) dolazimo do gotovo 50 posto ispitanika u čijim je poduzećima digitalna transformacija ili marginalna tema ili uopće nije na listi prioriteta. Nadalje, na pitanje o važnosti korporativne kulture za uspješno provođenje digitalne transformacije poslovanja, velika većina ispitanik smatra promjenu korporativne kulture iznimno važnim faktorom za uspješno digitalno transformiranje poduzeća, gdje gotovo $80 \%$ ispitanika smatra da je promjena korporativne kulture vrlo do iznimno važna za uspješnu digitalnu transformaciju poduzeća. 
Slika 4. Važnost digitalne transformacije za poduzeće Koje mjesto zauzima digitalna transformacija na listi prioriteta u
Vašem poduzeću?

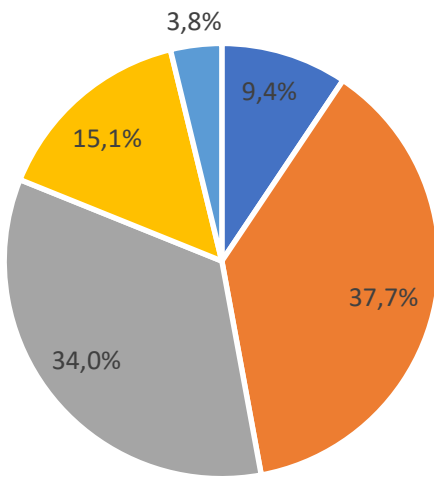

- To je najvažnija tema

- U prve 3 teme po važnosti

- U prvih 10 tema po važnosti

- Uopće nije na listi prioriteta

- Ne znam/Nisam siguran-a

Izvor: izračun autora

Što se tiče prepreka s kojima se poduzeća susreću pri pokušaju digitalnog transformiranja vlastitog poslovanja (Slika 5), one se mogu rasporediti u tri skupine s obzirom na to koliko ih učestalo ispitanici identificiraju kao prepreke u procesu digitalne transformacije. Ispitanici na prvo mjesto stavljaju financijske (povećani troškovi) i operativne (postojeći prioriteti poslovanja) prepreke, na drugom mjestu se nalaze nedostatak vremena $\mathrm{i}$ iskustva potrebnog za provođenje digitalne transformacije, dok na trećem mjestu se nalaze ostali razlozi koji variraju od straha od promjena do otpora menadžmenta poduzeća. 
Slika 5. Prepreke pri provođenju digitalne transformacije

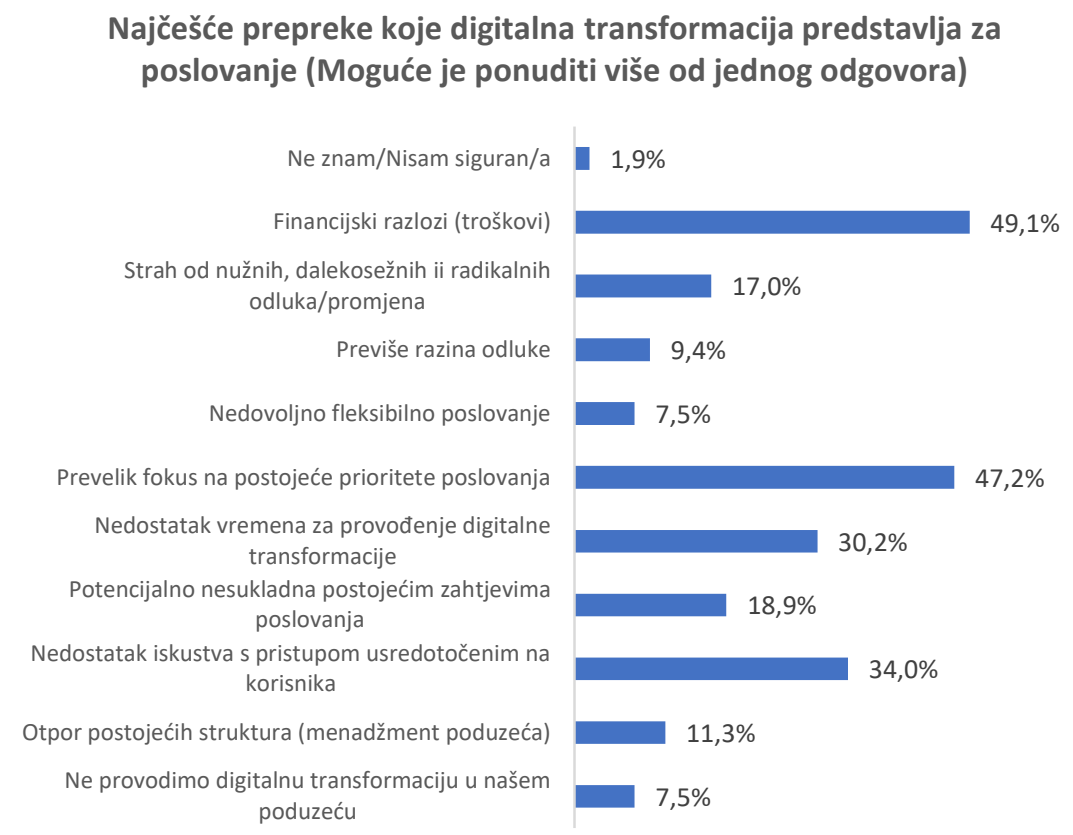

Izvor: izračun autora

Procjena utjecaja digitalizacije i digitalne transformacije na poduzeće i njegove sastavnice od strane ispitanika vrlo dobro ilustrira svijest o nužnosti prilagodbe digitalnoj ekonomiji i svemu što ona nosi sa sobom. Naime, na pitanje o utjecaju digitalizacije i digitalne transformacije na poslovanje, gotovo $50 \%$ ispitanika se slaže da će se posljedice digitalizacije (bila ona uspješno ili neuspješno provedena) osjetiti u razdoblju do 3 godine. Kada tome pribrojimo i one ispitanike koji smatraju da će se posljedice vidjeti u razdoblju do 5 godina, dolazimo do preko $70 \%$ ispitanika koji su svjesni važnosti digitalizacije i digitalne transformacije, te učinaka (bilo pozitivnih, bilo negativnih) koje ti procesi imaju na poslovanje poduzeća.

Digitalna transformacija kao vrlo kompleksan proces, kao što je i naznačeno $\mathrm{u}$ drugim dijelovima ovog rada, zahtjeva formaliziran okvir za provođenje, a koji bi se najbolje mogao opisati kao strategija digitalne transformacije. Po pitanju razvoja strategije digitalne transformacije (Slika 6), gotovo 90\% ispitanika potvrdilo je da imaju razvijenu strategiju (17\%) ili imaju u planu razviti strategiju digitalne transformacije $(71,7 \%)$. 
Slika 6. Strategija digitalne transformacije

Imate li razvijenu strategiju digitalne transformacije?

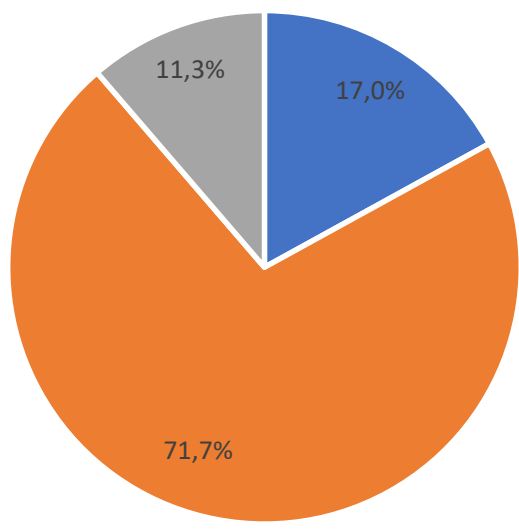

- $\mathrm{Da}$

- Ne, ali imamo u planu razviti je

- Ne, niti je planiramo razviti

Izvor: izračun autora

S druge strane gotovo $60 \%$ ispitanika potvrđuje da njihova poduzeća provode digitalnu transformaciju (Slika 7), što implicira, ako uzmemo u obzir i odgovore na pitanje da li imaju razvijenu strategiju digitalne transformacije, da nisu svi procesi digitalne transformacije planirani i vođeni kroz neki oblik strateškog okvira.

Razvidno je da postoji nekoliko pristupa procesu digitalne transformacije među poduzećima iz sektora maloprodaje, s najistaknutijom razlikom da su neki procesi formalizirani kroz strateški okvir, dok ostali to nisu.

S obzirom na dosad navedene učinke digitalizacije i digitalne transformacije na poduzeće, na pitanje o utjecaju digitalizacije i digitalne transformacije na poslovni model njihova poduzeća, gotovo $50 \%$ ispitanika smatra da će se poslovni model njihovih poduzeća malo ili nimalo izmijeniti, dok ih nešto manje od $40 \%$ smatra da će se poslovni model njihovih poduzeća značajno izmijeniti.

Također, ispitanici su najčešće birali upravo poslovni model njihovih poduzeća kao područje na koje će procesi digitalizacije i digitalne transformacije imati najveći utjecaj. Zaposlenici i infrastruktura predstavljaju sastavnice poduzeća, za koja ispitanici smatraju da će se također naći pod velikim utjecajem digitalizacije i digitalne transformacije, iako ne u tolikoj mjeri kao poslovni model poduzeća. 
Slika 7. Implementacija digitalne transformacije u poduzećima

Provodi li Vaše poduzeće digitalnu transformaciju?

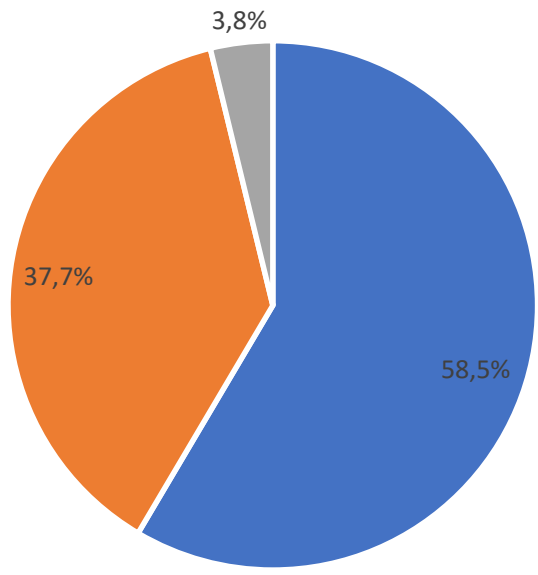

Izvor: izračun autora

Ispitanici su najučestalije birali (više od 70\%) interne procese poduzeća kao one procese koji se primarno moraju naći u fokusu digitalne transformacije, dok se komunikacija s potrošačima odnosno kupcima, nalazi na drugom mjestu, s rezultatom od oko 50\%. Međutim, ispitanici su kao treći i četvrti najučestaliji odgovor, birali područja povezana s potrošačima odnosno kupcima (odnosi s kupcima, praćenje ponašanja potrošača), što govori da su i odnosi s kupcima i sve povezano s tim područjem prepoznati kao područje gdje se očekuje najveći iskorak u procesu digitalne transformacije. 
Slika 8. Utjecaj digitalne transformacije na poslovne procese

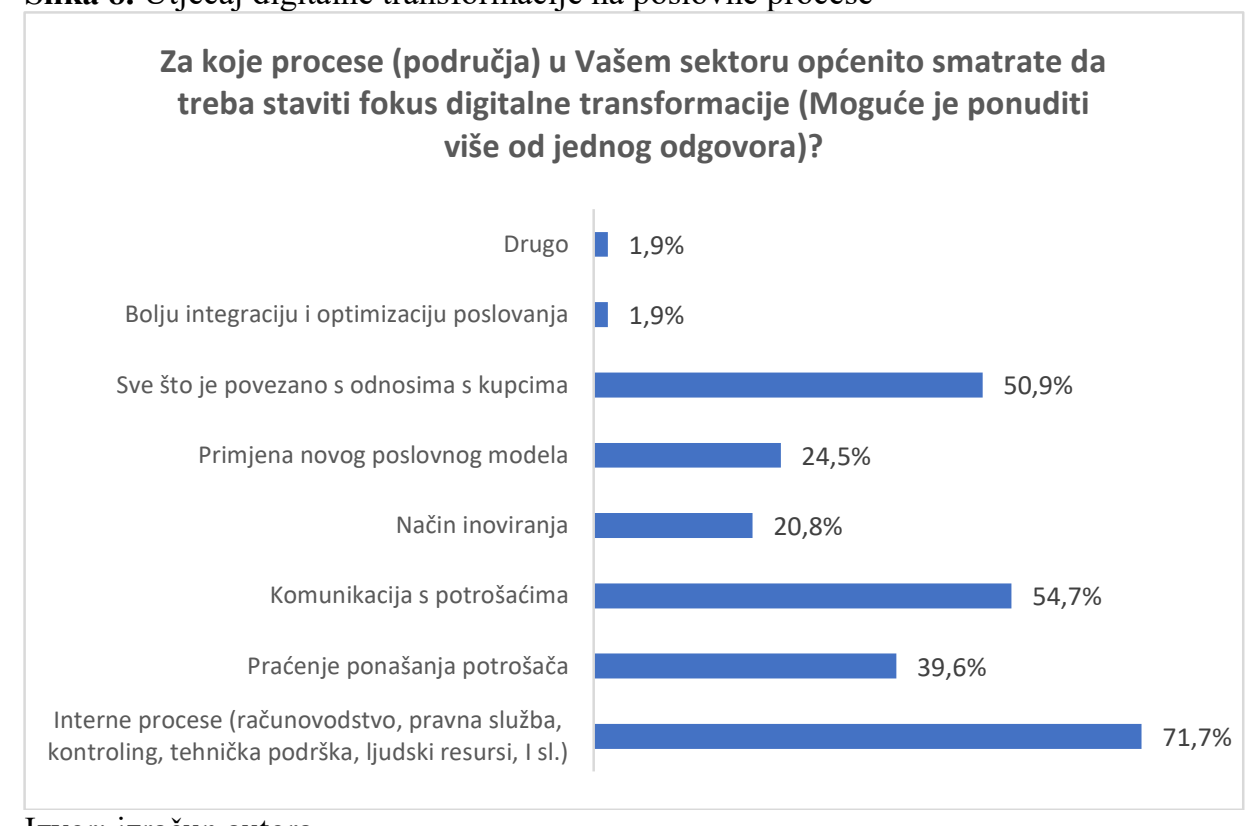

Izvor: izračun autora

Među poduzećima koja provode digitalnu transformaciju, u više od njih 80 posto, sam proces je vođen od čelnih ljudi poduzeća, bilo to predsjednici uprava ili članovi uprava. Ovaj podatak jasno pokazuje da je proces digitalne transformacije vrlo ozbiljno shvaćen u poduzećima iz sektora maloprodaje, odnosno onim poduzećima iz sektora maloprodaje koja i provode digitalnu transformaciju vlastitog poslovanja.

Od mjera i aktivnosti kojima se u poduzećima iz sektora maloprodaje nastoji implementirati proces digitalne transformacije, najčešće su one vezane za pojačanu edukaciju zaposlenika o digitalnim temama (više od 50\%). Druge najučestalije mjere odnose se na korištenje usluga vanjskih konzultanata $(35,8 \%)$, te na mjere bolje integracije metoda za fokus na potrošače (34\%). Ostale mjere su značajno manje zastupljene, a odnose se na uspostavu novog digitalnog odjela $(13,2 \%)$, odnosno na organiziranje digitalnog odjela kao podružnice $(13,2 \%)$, te aktivnost usvajanja metoda za agilan razvoj proizvoda $(13,2 \%)$. 
Slika 9. Mjere i aktivnosti pri oblikovanju digitalne transformacije Koje mjere i aktivnosti, od navedenih, koristite za oblikovanje
digitalne transfromacije? (Moguće je ponuditi više od jednog
odgovora)

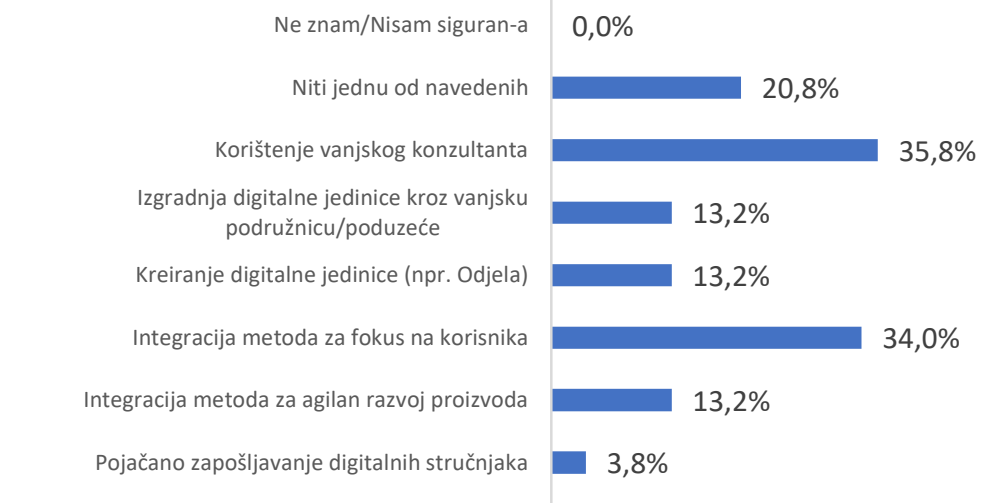

Pojačana edukacija zaposlenika o digitalnim temama

Izvor: izračun autora

S obzirom na kapacitete zaposlenika za provedbu digitalne transformacije, stvari nisu toliko jasne, budući da je više od 80 posto ispitanika potvrdilo da su njihovi zaposlenici tek djelomično osposobljeni za provođenje digitalne transformacije, dok je njih nešto manje od 10 posto potvrdilo da su njihovi zaposlenici u potpunosti kvalificirani provesti digitalnu transformaciju. Međutim, ono što pomalo zabrinjava, je da gotovo pola ispitanika (47,2\%), svoje zaposlenike ne priprema za digitalnu transformaciju i to iz razloga što nemaju odgovarajuće mehanizme. Nešto malo manje od 40 posto $(37,7 \%)$ ispitanika kao način pripreme zaposlenika za izazove digitalne transformacije navodi edukaciju zaposlenika o digitalnim vještinama i agilnim metodama, te to ujedno predstavlja i najčešće korištenu mjeru odnosno aktivnost kojom se zaposlenici pripremaju na promjene u poslovanju koje će donijeti digitalna transformacija.

Korporativna kultura neminovno se mijenja pod utjecajem digitalne ekonomije, a u tom procesu kao najučestalija mjera kojom se nastoji prilagoditi korporativnu kulturu novom digitalnom okruženju i omogućiti poticanje digitalizacije i inovacija navodi se korištenje suvremenih sredstava komunikacije (66\%). Drugu skupinu mjera kojima se nastoji potaknuti prilagodba korporativne kulture digitalnom dobu su: jačanje osobne odgovornosti zaposlenika $(20,4 \%)$, fleksibilnost po pitanju načina rada $(18,9 \%)$. U treću skupinu spadaju uspostava kulture koja također vrednuje pogrešku ili uspjeh $(13,2 \%)$, te pojednostavljenje organizacijske hijerarhije $(13,2 \%)$. Zabrinjavajuća je činjenica da više od 20 posto ispitanika navodi da ne poduzimaju nikakve mjere. 
Slika 10. Najveće prijetnje konkurentnosti

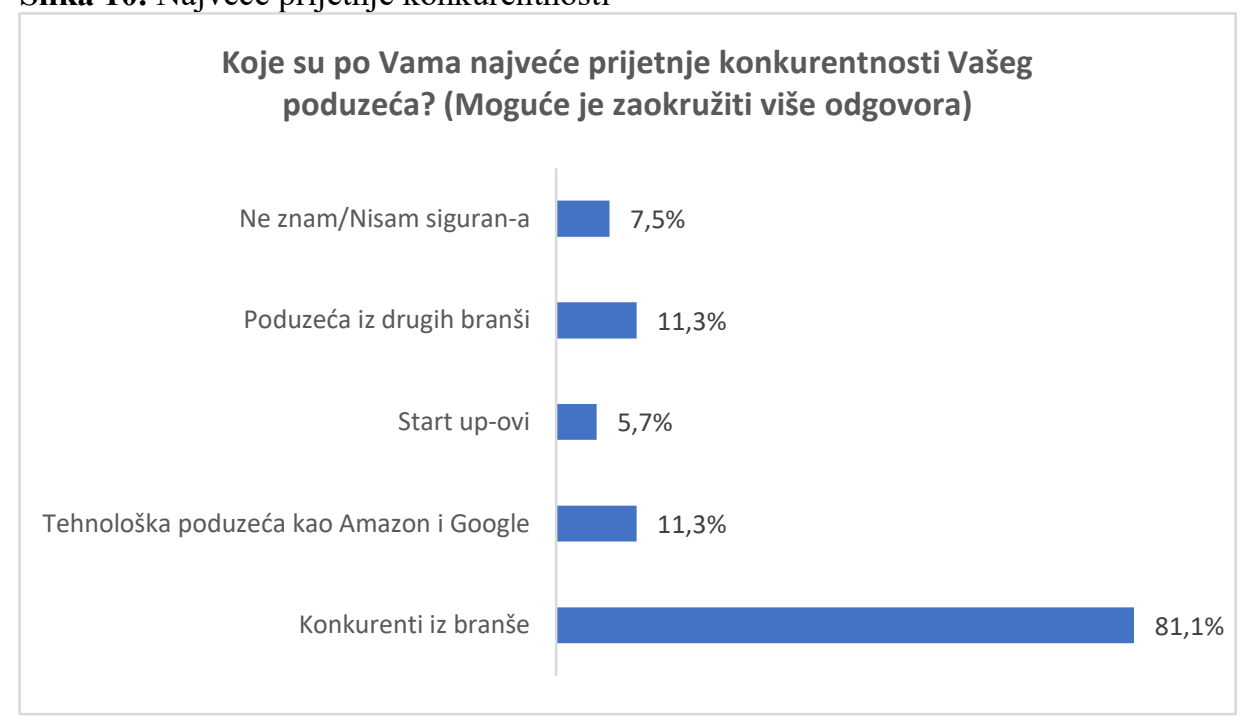

Izvor: izračun autora

Nadalje, kao najveću prijetnju konkurentnosti vlastitog poduzeća, ispitanici u velikoj mjeri $(81,1 \%)$ navode konkurente iz sektora maloprodaje. Globalni tehnološki divovi (poput Amazon-a ili Google-a), start-up poduzeća ili poduzeća iz drugih sektora, iz vizure poduzeća iz sektora maloprodaje, ne predstavljaju veliku prijetnju za njihovu konkurentnost. Po pitanju tehnologija odnosno digitalnih trendova koji će najviše utjecati na poslovni model poduzeća iz sektora maloprodaje, ispitanici vide razvoj digitalnih platformi $(81,1 \%)$ kao nešto čemu će se najviše prilagođavati njihov poslovni model. Također, dobra dio ispitanika smatra da će inkorporiranje Big Data/Smart Data sustava $(30,1 \%)$, Umjetne inteligencije $(20,8 \%)$ te Interneta stvari $(17 \%)$ imati veliki utjecaj na njihov poslovni model (Slika 11). 
Slika 11. Utjecaj tehnologija i trendova na poslovanje

Koja će tehnologija ili digitalni trendovi, od sljedećih, imati najveći utjecajna Vaš konkretan poslovni model tijekom slijedeće tri godine?

(Moguće je ponuditi više od jednog odgovora)

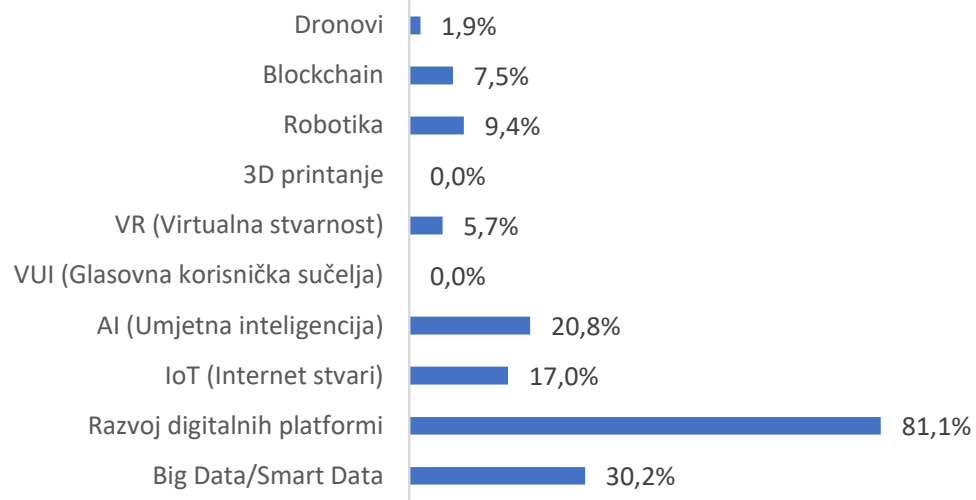

Izvor: izračun autora

Kada sumiramo rezultate istraživanja, možemo zaključiti da se poduzeća iz sektora maloprodaje mogu jasno podijeliti na ona poduzeća koja su ozbiljno shvatila promjene koje im donosi novo digitalno okruženje, te su se sustavno, kroz jedan formalizirani okvir, počele prilagođavati novoj (digitalnoj) stvarnosti, te ona poduzeća koja toga još nisu u potpunosti svjesna. Nadalje, poduzeća se na svojem putu digitalne transformacije najčešće susreću sa preprekama financijske i/ili operativne naravi. U fokus svoje prilagodbe digitalnom okruženju, poduzeća iz sektora maloprodaje, velikom većinom izabiru razvoj novih digitalnih platformi, dok se interno fokusiraju na digitalizaciju i reorganizaciju vlastitih internih procesa. Fokus na potrošače i cjelokupne odnose s njima, još uvijek je sekundarna tema u procesu digitalizacije i digitalne transformacije poduzeća iz sektora maloprodaje.

\section{ZAKLJUČAK I PREPORUKE ZA PROVEDBU DIGITALNE TRANSFORMACIJE MALOPRODAJE}

Mnoga recentna istraživanja potvrdila su da današnji trgovci prepoznaju kontinuirano mijenjanje navika potrošača te nužnost osiguravanja potrošačima vrhunskog iskustva putem bilo kojeg kanala komunikacije. One maloprodaje koji nisu jasno definirale kanale komunikacije niti imaju izrađenu strategiju digitalne transformacije vrlo brzo će osjetiti pad broja potrošača, prodaje i profita. Pritom treba imati na umu da mnogi trgovci koji navode da digitalno transformiraju svoje poslovanje, 
u većini slučajeva nisu puno napravili na području promjene organizacijske kulture sukladno postavljenim ciljevima digitalne transformacije poslovanja, odnosno ne primjenjuju adekvatno strategiju komunikacije prema kupcima koja se temelji na različitim kanalima komunikacije.

Digitalna transformacija maloprodajnog sektora, potpomognuta prediktivnom analitikom, nužna je za neprekidno kreiranje „najboljeg prodajnog iskustva“"za potrošača, a čime se stvara veća lojalnost potrošača i rast prodaje. Ali za kreiranje „najboljih iskustava" više nije dovoljna implementacija maloprodajne strategije bez individualiziranog fokusa na korisničko putovanje potrošača (customer-journey), razumijevanja njegovih navika i stvarnih potreba. Privlačenje i zadržavanje potrošača stoga zahtijeva sustavno ulaganje $\mathrm{u}$ suvremene tehnologije $\mathrm{s}$ ciljem promjena $\mathrm{u}$ maloprodaji usmjerenih prema zadovoljenju ključnih potrošačevih želja i potreba. Kao rezultat ovih napora trgovci u maloprodaji ubrzano prilagođavaju poslovne modele $\mathrm{i}$ povećavaju ulaganja u tehnologije koje im omogućuju predviđanje potreba kupaca te neprekidno usklađivanje poslovanja s tim potrebama.

Posljednjih nekoliko godina proveden je veliki broj analiza s ciljem boljeg razumijevanja ponašanja potrošača, identifikacije njegovih stvarnih potreba, te identifikacije trendova u maloprodaji (npr. Digital Transformation in Retail, Fujitsu Future Insights, 2019. godina; Key Success Factors for Digital Transformation in the Retail Industry (White Paper), TCS Digital Software \& Solutions for IDC, 2015. godina; Digital transformation in the retail and consumer industry, PWC). Većina tih analiza $i$ studija ukazuju na četiri ključna čimbenika uspješnosti koje poduzeća u maloprodaji moraju zadovoljiti kako bi ostvarili uspjeh u suvremenom svijetu:

1. Pružiti "najbolje iskustvo" u svakoj interakciji s potrošačem

2. Bolje upoznati potrošača i razumjeti njegove potrebe sa svakom sljedećom interakcijom

3. Usredotočiti se na individualizirani pristup potrošaču kroz sve kanale komunikacije

4. Osigurati agilnost $u$ poslovanju, provesti digitalnu transformaciju poslovanja, $\mathrm{i}$ primijeniti suvremenu digitalnu tehnologiju u maloprodaji.

Potrošači ocjenjuju maloprodaju prema njihovom posljednjem "najboljem iskustvu". Svaki trgovac koji se želi pozicionirati na prvo mjesto potrošačeve kupnje, treba potrošaču osigurati najbolje iskustvo interakcije. To zahtijeva agilnost trgovca $u$ prilagođavanju pritiscima konkurencije i implementaciji promjena sukladno potrebama potrošača. Ta sposobnost se temelji na boljem slušanju, razumijevanju, te pružanju inovativnih i atraktivnih mogućnosti putem višenamjenskih platformi (omni-channel platforms).

Kako bi se, prije svega, formulirala strategija digitalne transformacije u sektoru maloprodaje, potrebno je, kao i kod bilo koje druge poslovne strategije, napraviti analizu s ciljem boljeg razumijevanja potreba kupaca. Dublje razumijevanje navika i potreba kupca pomaže trgovcu u procesu donošenja boljih odluka u aktivnostima prilagodbe marketinških aktivnosti, identificiranja i distribucije najboljih proizvoda, upravljanju cijenama, razumijevanju potražnje te optimizaciji prihoda i profitabilnosti. Ulaganja u 
digitalne tehnologije za analizu navika potrošača trebaju imati prioritet jer su spomenute tehnologije preduvjet za bolje upravljanje zalihama, financijsko planiranje, predviđanje potražnje na tržištu i upravljanje narudžbama. Danas svi uspješni trgovački lanci koriste različite softvere za upravljanje informacijama (MIS), upravljanje skladištem te različite sofisticirane alate za predviđanje s ciljem optimizacije zaliha i njihove distribucije.

Za individualizirani pristup potrošaču kroz sve kanale komunikacije/interakcije, potrebna su specifična ulaganja u tehnologiju usmjerena prema digitalnim i više-kanalnim inicijativama, te prema prikupljanju dovoljne količine podataka potrebne za individualizirani pristup kupcu. Napredni i uspješni trgovci usmjeravaju tehnologiju i svoje aktivnosti prema boljem razumijevanju potreba i iskustava kupaca koristeći napredne digitalne i tehnološke alate koje će, u određenom trenutku, dovesti do povezivanja kupca i trgovca na dnevnoj razini, odnosno to će postati kontinuirana interakcija na osnovama koncepta industrije 4.0.

Informiranost o svim događanjima u okruženju, u svakom trenutku, više nije opcija već nužnost suvremenog maloprodajnog poslovanja. Digitalizacija i primjena tehnoloških rješenja ključni su za adekvatno razumijevanje tržišta i potrošača, te dobivanje pravovremenih informacija koje se potom koriste za bržu reakciju i donošenje odluka s ciljem održavanja konkurentnosti te pravovremene prilagodbe poslovanja. Agilno i digitalizirano poslovanje uz potporu specifičnih i prilagođenih tehnoloških rješenja ključni su za bržu implementaciju promjena u poslovnom sustavu i na tržištu. Također, svaki suvremeni maloprodajni eko-sustav morao bi stvoriti preduvjete za stvaranje inovacija i kontinuirano preispitivanje poslovnog modela koji primjenjuje, jer tradicionalni poslovni pristupi više nisu dovoljni za uspjeh u maloprodaji.

Poznavanje potrošača, mogućnost personalizacije proizvoda/usluge, te interakcija s potrošačima kroz različite kanale (kombinirajući digitalne kanale i fizičke prostore maloprodaje), prvi su preduvjeti rasta poslovanja maloprodaje u digitalnom dobu. Drugi preduvjet uspjeha leži u agilnom poslovnom sustavu, transformaciji poslovanja, primjeni digitalnih tehnologija te kontinuiranom propitivanju poslovnog modela i sposobnosti njegove brze promjene i prilagodbe. Maloprodajne organizacije koje ne osiguraju ove preduvjete neće biti sposobne pronaći brz i odgovarajuću pristup potrošačima te će s vremenom njihovo poslovanje i tržišna pozicija slabiti.

Ograničenja ovakvog tipa istraživanja prije svega se odnose na veličinu i izbor uzorka, te način provođenja istraživanja (online anketa), što je možda isključilo neka poduzeća iz uzorka. Prostor za nova istraživanja je poprilično velik budući da je sam proces digitalne transformacije i s njim povezanih procesa relativno slabo istražen $\mathrm{u}$ znanstvenoj literaturi. Međutim, valjalo bi posebno naglasiti nedostatak empirijskih istraživanja u Republici Hrvatskoj, a koja bi za cilj imala dublje istražiti elemente digitalne transformacije i njezinih utjecaja na poslovanje poduzeća. 


\section{LITERATURA:}

1. Boureanu L. (2017) From Customer Service to Customer Experience: The Drivers, Risks and Opportunities of Digital Transformation. In: Klewes J., Popp D., RostHein M. (eds) Out-thinking Organizational Communications. Management for Professionals. Springer, Cham. Pp 145-155 https://doi.org/10.1007/978-3-31941845-2 11

2. CISCO (2018) Cisco Annual Internet Report (2018-2023), Dostupno na: https://www.cisco.com/c/en/us/solutions/collateral/executive-perspectives/annualinternet-report/white-paper-c11-741490.pdf

3. Ćurić Martinčević, N. (2020) Digitalna transformacija u Hrvatskoj, Zagreb: Apsolon, Dostupno na: https://apsolon.com/publikacije/digitalna-transformacija-u-hrvatskoj2020/

4. Fujitsu (2019) Digital Transformation in Retail, Fujitsu Future Insights, Dostupno na: $\quad$ https://www.fujitsu.com/downloads/GLOBAL/vision/2019/downloadcenter/FTSV2019 wp3 EN_1.pdf

5. Gurbaxani, V i Dunkle, D. (2019) Gearing Up For Succesfull Digital Transformation, MIS Quarterly Executive, 2019, 18(3), pp 209-220. https://aisel.aisnet.org/misqe/vol18/iss3/6

6. Haffke, I., Kalgovas, B., i Benlian, A., (2016), The Role of the CIO and the CDO in an Organization's Digital Transformation, Publications of Darmstadt Technical University, Institute for Business Studies (BWL), Darmstadt Technical University, Department of Business Administration, Economics and Law, Institute for Business Studies (BWL). https://core.ac.uk/download/pdf/301370191.pdf

7. Hänninen, M., Smedlund, A., i Mitronen, L. (2018). Digitalization in retailing: multisided platforms as drivers of industry transformation. Baltic Journal of Management, 13(2), pp 152-168. https://doi.org/10.1108/BJM-04-2017-0109

8. IDC (2015) Key Success Factors for Digital Transformation in the Retail Industry (White Paper), TCS Digital Software \& Solutions for IDC, Dostupno na: https://www.tcs.com/content/dam/tcs/pdf/product-details/DSS/DSS-WhitepaperIDC-Key-Success-Factors-Digital-Transformation-Retail.pdf

9. Kane, G.C, Kiron, D., Palmer, D., Phillips A.N. i Buckley, N. (2015) Strategy, not Technology, Drives Digital Transformation, MIT Sloan Management Review and Deloitte University Press. https://www2.deloitte.com/content/dam/Deloitte/cn/Documents/technology-mediatelecommunications/deloitte-cn-tmt-strategy-not-technology-drive-digitaltransformation-en-150930.pdf

10. Kilkki, K., Mäntylä, M., Karhu, K., Hämmäinen, H., i Ailisto, H. (2018) A disruption framework, Technological Forecasting \& Social Change, 129, pp 275-284. https://doi.org/10.1016/j.techfore.2017.09.034

11. Kaufman, I. i Horton, C. (2014) Digital transforamtion: Leveriging Digital Technology with core Values to Achieve Sustainable Business Goals. The European Financial Review (December - January) pp 63-67. 
https://www.europeanfinancialreview.com/digital-transformation-leveragingdigital-technology-with-core-values-to-achieve-sustainable-business-goals/

12. Marchand, D. A. i Wade M.R. (2014) Digital business transformation: Where is your company on the journey, IMD, Dostupno na: https://www.imd.org/researchknowledge/articles/digital-business-transformation-where--is-your-company-onthe-journey/

13. Matt, C. Hess, T. i Benlian, A. (2015) Digital transformation strategies, Business \& Information Systems Engineering, 57, pp 339-343. https://doi.org/10.1007/s12599$\underline{015-0401-5}$

14. Meske, C. i Junglas, I., (2020) Investigating the elicitation of employees' support towards digital workplace transformation, Behaviour and Information Technology, published online: May 2020. https://doi.org/10.1080/0144929X.2020.1742382

15. Pantano, E. i Vanucci, V. (2019) Who is innovating? An exploratory research of digital technologies diffusion in retail industry, Journal of Retailing and Consumer Services, 49, pp 297-304.

16. PWC (2018) Digital transformation in the retail and consumer industry, Dostupno na: $\quad$ https://www.pwc.co.uk/services/consulting/accelerate-digital/retail-digitaltransformation.html

17. Schallmo D, Williams C.A, i Boardman L. (2017) Digital transformation of business models - Best practices, enablers and roadmap. International Journal of Innovation Management, 21(8), pp 1-17. https://doi.org/10.1142/S136391961740014X

18. Skog, D.A., Wimelius, H. i Sandberg, J. (2018) Digital Disruption. Business and Information Systems Engineering 60, pp 431-437. https://doi.org/10.1007/s12599018-0550-4

19. Tekic, Z. i Koroteev, D. (2019) From disruptively digital to proudly analog: A holistic typology of digital transformation strategies, Business Horizons 62(6), pp 683-693. https://doi.org/10.1016/j.bushor.2019.07.002

20. Verhoef, P. C., Broekhuizen, T., Bart, Y., Bhattacharya, A., Qi Dong, J., Fabian, N. i Haenlein, M. (2019) Digital transformation: A multidisciplinary reflection and research agenda. Journal of Business Research, (Available online 2 November 2019). https://doi.org/10.1016/j.jbusres.2019.09.022

21. Von Leipzig, T., Gamp, M. Manz, D., Schottle K., Ohlhausen, P., Oosthuizen, G., Palm, D. von Leipzig, K. (2017) Initialising customer-orientated digital transformation in enterprises, Procedia Manufacturing 8, pp 517-524. https://doi.org/10.1016/j.promfg.2017.02.066

22. Warner, K. i Wager, M. (2019) Building dynamic capabilities for digital transformation: An ongoing process of strategic renewal, 52(3), pp 326-349. https://doi.org/10.1016/j.lrp.2018.12.001

23. Wessel, L., Baiyere, A., Ologeanu-Taddei, R. i Cha, J. Jensen, T.B. (2020) Unpacking the Difference between Digital Transformation and IT-enabled Organizational Transformation. (forthcoming) Journal of the Association for Information Systems. https://research.cbs.dk/en/publications/unpacking-thedifference-between-digital-transformation-and-it-en 
24. Wessel, M. i Christensen M. C. (2012), Surviving disruption, Harvard Business Review, 90 , $\mathrm{pp}$ $56-64$. https://www.naadac.org/assets/2416/kim_johnson_ac15 bhbusiness ho2.pdf 


\title{
DIGITAL TRANSFORMATION OF RETAIL BUSINESS
}

\begin{abstract}
Summary
The paper examines the process of digital transformation with special emphasis on the state of digital transformation in the retail sector. In addition to the analysis of key elements of the digital transformation and inquiry into global changes in the retail sector driven by digitization, a research was conducted that confirmed the already well-known assumptions about digital readiness of Croatian retail sector, as well as the state of digitalization and digital transformation of Croatian retail sector. Namely, even though majority of companies in the sample are aware of the challenges posed by the new digital environment, digitalization and digital transformation are not seen as a priority for all actors in the sector. The reasons behind inactivity are very often of a financial or operational nature. Companies from the sector, are predominantly, focused on the development of new digital platforms, and internally they primary focus is on the digitalization of internal processes. The focus on consumers and overall relationships with them is still a secondary topic in the process of digitalization and digital transformation of companies in the retail sector. Finally, companies from the retail sector in this study can be clearly divided into two groups: companies which are actively working on digitalization and digital transformation and those which do not.
\end{abstract} Croatia.

Key words: digital transformation, digitalization, new business models, retail, 